\title{
A critical evaluation of the methods for the determination of required volumes for detention tank
}

\author{
Mariusz Starzec ${ }^{1, *}$ \\ ${ }^{1}$ Rzeszow University of Technology, Department of Infrastructure and Water Management, \\ al. Powstańców Warszawy 6, 35-959 Rzeszów, Poland
}

\begin{abstract}
Simplified methods allow a straightforward and quick determination of parameters of interest. A simplified method of calculation to be used must provide sufficiently accurate simulation results. This paper presents the results of tests completed to evaluate the effects of the parameters which describe a sewer catchment area and network on the value of $T_{p}$, a parameter applied in the Dziopak method [18]. The results of 2997 hydrodynamic simulations allowed to formulate an artificial neural network the application of which enabled the determination of the value of $T_{p}$ dependent on the design parameters of a sewer catchment area and network. The artificial neural network had a very low error $R^{2}=0.9972$ between the expected and determined values of $T_{p}$. The completed tests indicated a relationship by which an increase of the rainfall duration, a parameter used in the dimensioning of detention tank, is concomitant to an increase in the value of $T_{p}$. The calculations made so far included an assumption that the $T_{p}$ value is constant irrespective of the design rainfall duration for the dimensioning of detention tank; this assumption has led to gross calculation errors. The paper also provides proof that the inclusion of these relationships allows a more precise determination of the service volume required for a multi-chamber detention tank.
\end{abstract}

\section{Introduction}

Sewage systems are among the most expensive and the most difficult to implement, especially when operating in a gravity system $[1,2]$. The most capital-intensive type of sewage system is the rainwater sewage system. In order to improve its operation, for many years they have been equipped with various types of detention tanks [3, 4]. However, it should be remembered that the choice of the appropriate project option should be supported by the analysis of many indicators [5,6], including in particular a technical and financial [7-9], and environmental [10,11] analysis, taking into account the lifespan of the investment[12-14].

The service volume of a detention tank is determined from a balance of detention tank waste water inflow and outflow during the filling of the detention tank $[15,16]$. The service

\footnotetext{
* Corresponding author: mstarzec1990@prz.edu.pl
} 
volume is a function of a surface area determined between the lines of the hydrographs which depict the waste water inflow and outflow rates to and from the detention tank during a critical rainfall $[17,18]$. The maximum waste water inflow rate from the sewer catchment area to the detention tank occurs with a certain delay. It is the total of the waste water flow time along the worst-case branch of the sewer network and the time of concentration.

Through hydrodynamic design engineering, it is possible to precisely determine the service volume required for the detention tank. Note that this method is time-consuming and requires an expert knowledge of drainage and sewerage systems. It is then prudent to apply simplified methods at the preliminary calculation stage. Polish design engineers can apply the Dziopak computational models to determine the service volumes required for detention tank in sewerage systems. The simplified models and formulas presented in [18] provide a straightforward and quick determination of the service volume required for multichamber detention tank. The simplified models and formulas were determined with the relationships which should be updated after some time. It is prudent to improve the developed methods to reduce the calculation errors in relation to the results of hydrodynamic simulations. The preliminary tests indicated that the parameter which would require periodic updating was $T_{p}$, which determines the time required for the determination of the design waste water inflow rate of the detention tank. Before this work was completed, $T_{p}$ designated the rainfall duration for the dimensioning of the inflow sewer of a designed detention tank. However, previous research carried out by the author suggests that as the rainfall time is extended, the waste water flow time in the sewer network and the field concentration time increase. Hence, this paper presents a new procedure for the determination of $T_{p}$ the application of which largely reduces calculation errors.

The objective of the tests was to determine the effect of the sewerage catchment basin and network parameters on the value of $T_{p}$. The analysis results will aid the design engineers of sewerage networks and works in the precise determination of the parameter. This will simplify the hydrodynamic modelling calculations necessary for the determination of the service volume required for retention works.

\section{Theory and calculation}

The subject of the tests contemplated in this work was to determine the effect of the sewerage catchment area and the network parameters for the value of $T_{p}$, a parameter applied in the [18] method, described with the following formula (1):

$$
V W=\left(Q_{A}-Q_{O}\right) \cdot\left[T M W-\left(Q_{A}\right)^{-1} \cdot Q_{O} \cdot T_{p}\right\rfloor \cdot 60
$$

with: $V W$ - service volume required for a multi-chamber detention tank $\left[\mathrm{m}^{3}\right] ; Q_{A}-$ maximum waste water inflow rate of the detention tank $\left[\mathrm{m}^{3} / \mathrm{s}\right] ; Q_{O}$ - waste water outflow rate of the detention tank $\left[\mathrm{m}^{3} / \mathrm{s}\right] ; T M W$ - critical design rainfall time for the dimensioning of the detention tank [min]; $T_{p}$ - time to the maximum waste water inflow rate of the detention tank from the beginning of rainfall [min].

The adopted parameters were classified into three primary groups:

- the model input parameters;

- the output parameter;

- the constant parameters.

The output parameter in the tests was the value of $T_{p}$. The constant parameter was the rainfall frequency $C=2$ years. The unit rainfall intensity was determined with the Bogdanowicz-Stachy formula [19], which is the relationship between the rainfall intensity and the rainfall duration. The rainfall duration time interval for the test simulation was 10 200 minutes. In the research assumed that the width of the subcatchment is doubled the length of the calculation section of the sewage network [20]. Shape of catchment $N$ 
corresponds to the quotient of the catchment's length to its width. The value range for the individual input variables adopted in the analysis is shown in Table 1.

The test simulation results were generated in a hydrodynamic modelling software package called SWMM 5.1. The objective of the tests was to determine the value of $T_{p}$ at various configurations of its defining factors.

The tests were done on a data set which included the results of the hydrodynamic simulations of the operation of assumed drainage basins (catchment areas). The analysis tested the variation of $T_{p}$ in response to a variation of a single input parameter of the model without any alteration of the remaining parameters. An example of a part of the data inputs for the analysis is shown in Table 2. A total of 2997 different configurations of the drainage basin was tested.

Table 1. Sewerage catchment area and sewage network parameters as the test inputs.

\begin{tabular}{|c|c|c|}
\hline Independent variable & Minimum value & Maximum value \\
\hline Catchment area drainage, $F$ & $20 \mathrm{ha}$ & $100 \mathrm{ha}$ \\
\hline Catchment roughness, $n_{z}$ & $0.011 \mathrm{~s} / \mathrm{m}^{1 / 3}$ & $0.015 \mathrm{~s} / \mathrm{m}^{1 / 3}$ \\
\hline Catchment roughness coefficient, $\Psi$ & 0.25 & 0.75 \\
\hline Slope of catchment, $i_{z}$ & $2 \%$. & $10 \%$ o \\
\hline Shape of catchment, $N$ & 1 & 5 \\
\hline Slope of sewage network, $i_{s}$ & $2 \%$. & $10 \%$ o \\
\hline Catchment load, $O z$ & $4 \mathrm{ha} / \mathrm{km}$ & $10 \mathrm{ha} / \mathrm{km}$ \\
\hline Duration of precipitation, $t_{d}$ & $10 \mathrm{~min}$ & $200 \mathrm{~min}$ \\
\hline
\end{tabular}

Table 2. Parameter values adopted in the test analysis.

\begin{tabular}{|c|c|c|c|c|c|c|c|c|}
\hline $\begin{array}{l}\frac{\grave{D}}{\mathrm{E}} \\
\frac{\bar{E}}{\bar{Z}}\end{array}$ & 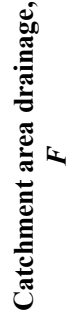 & 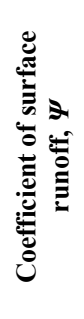 & 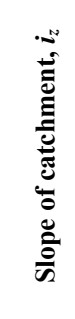 & 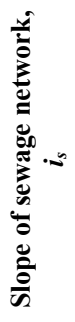 & 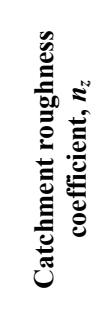 & 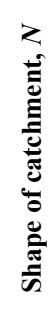 & 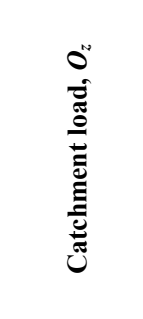 & 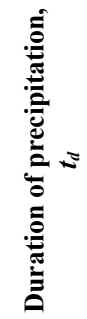 \\
\hline & [ha] & {$[-]$} & {$[\% 0]$} & [\%o] & {$\left[\mathrm{s} / \mathrm{m}^{1 / 3}\right]$} & {$[-]$} & {$[10 \cdot \mathrm{ha} / \mathrm{km}]$} & [min] \\
\hline 1 & 50 & 0,5 & 0,2 & 0,2 & 0,013 & 5 & 40 & 10 \\
\hline 2 & 100 & 0,5 & 0,2 & 1 & 0,015 & 5 & 100 & 10 \\
\hline 3 & 25 & 0,5 & 1 & 0,2 & 0,011 & 5 & 40 & 10 \\
\hline$\ldots$ & $\ldots$ & $\ldots$ & $\ldots$ & $\ldots$ & $\ldots$ & $\ldots$ & $\ldots$ & $\ldots$ \\
\hline 1561 & 100 & 0,75 & 0,2 & 0,2 & 0,015 & 3 & 40 & 29 \\
\hline 1562 & 50 & 0,5 & 0,5 & 0,2 & 0,013 & 5 & 70 & 29 \\
\hline 1563 & 25 & 0,25 & 1 & 1 & 0,015 & 3 & 70 & 29 \\
\hline$\ldots$ & $\ldots$ & $\cdots$ & $\ldots$ & $\ldots$ & $\cdots$ & $\ldots$ & $\ldots$ & $\ldots$ \\
\hline 2995 & 50 & 0,25 & 0,2 & 1 & 0,015 & 5 & 40 & 200 \\
\hline 2996 & 100 & 0,25 & 0,2 & 0,2 & 0,015 & 1 & 70 & 200 \\
\hline 2997 & 50 & 0,25 & 0,2 & 1 & 0,013 & 1 & 100 & 200 \\
\hline
\end{tabular}


The relationship between the value of $T_{p}$ and the included sewerage catchment area and network parameters was determined with artificial neural networks. The Statistica software package was applied to generate the relationship. The data outputs from the hydrodynamic simulations were divided in an artificial neural network wizard into: test data $(70 \%$ of the total data), teaching data ( $15 \%$ of the total data) and validation data ( $15 \%$ of the total data). Among the generated artificial neural networks, the one qualified for use had the lowest error and the highest match.

\section{Results and discussion}

The artificial neural network with the highest teaching quality (0.998618), the highest testing quality (0.998542) and the highest validation quality (0.998231) was an $M L P$ network with an 8-11-1 structure.

A comparison of the test results from the hydrodynamic modelling to the test results calculated with the artificial neural networks revealed slight differences only. Fig. 1 shows the values determined from the hydrodynamic simulations (the expected values) and the values calculated with the developed artificial neural network model (the produced values).

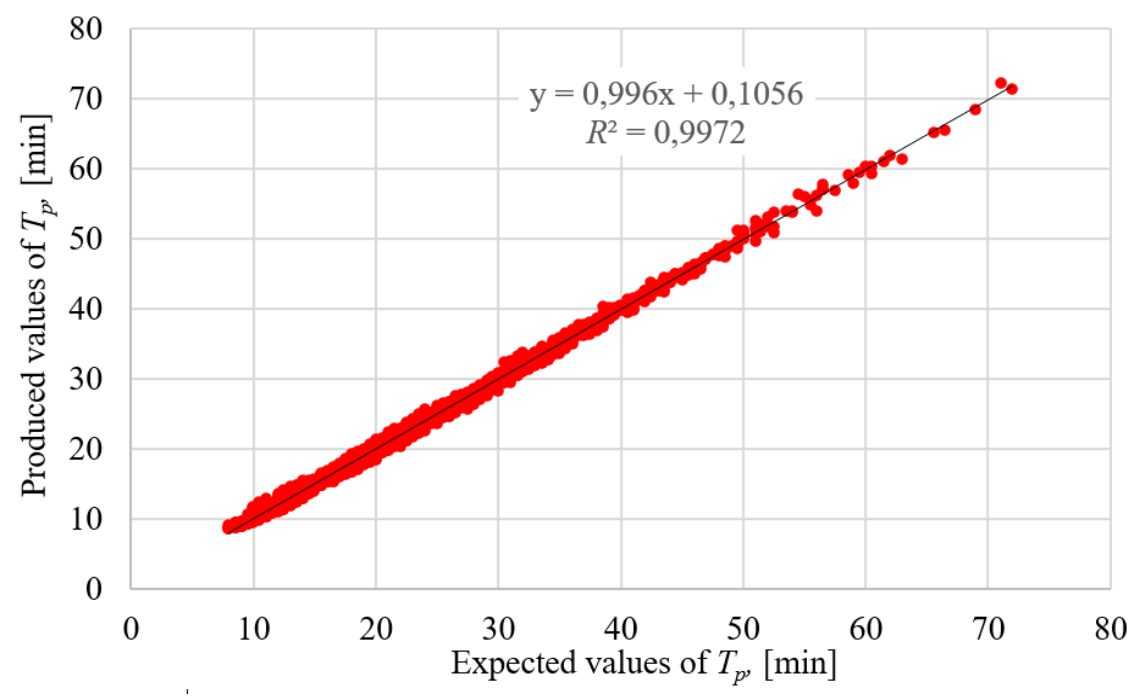

Fig. 1. Expected and produced values of $T_{p}$.

The data in Fig. 1 show a very good linear dependence between the expected values (from the hydrodynamic simulations) and the values produced with the artificial neural network, proven by the high value of the determination factor, $R^{2}=0.9972$.

Fig. 2 shows the values of $T_{p}$ in relation to the rainfall duration for the specific drainage basin. The blue curve shows the $T_{p}$ determined from the hydrodynamic simulations. The red curve shows the $T_{p}$ values determined by the application of the artificial neural network. Note that the determined $T_{p}$ values (the red curve) describe the expected $T_{p}$ values (the blue curve) with a very close dependence and through the entire rainfall duration. The highest percentage error of $T_{p}$ at $3.85 \%$ was determined for the rainfall duration of 110 minutes.

A study of the curves in Fig. 2 readily shows that the $T_{p}$ time to the maximum waste water inflow rate of the detention tank was increasing with the rainfall duration. The relationship was caused by a reduction of the waste water flow rate in the sewerage network and the extension of the field concentration time, coupled with an increase in the rainfall duration. The relationship occurred for all tested drainage variants. The method presented 
in [18] always had an assumption that $T_{p}$ was constant irrespective of the rainfall duration applied for the dimensioning of detention tank.

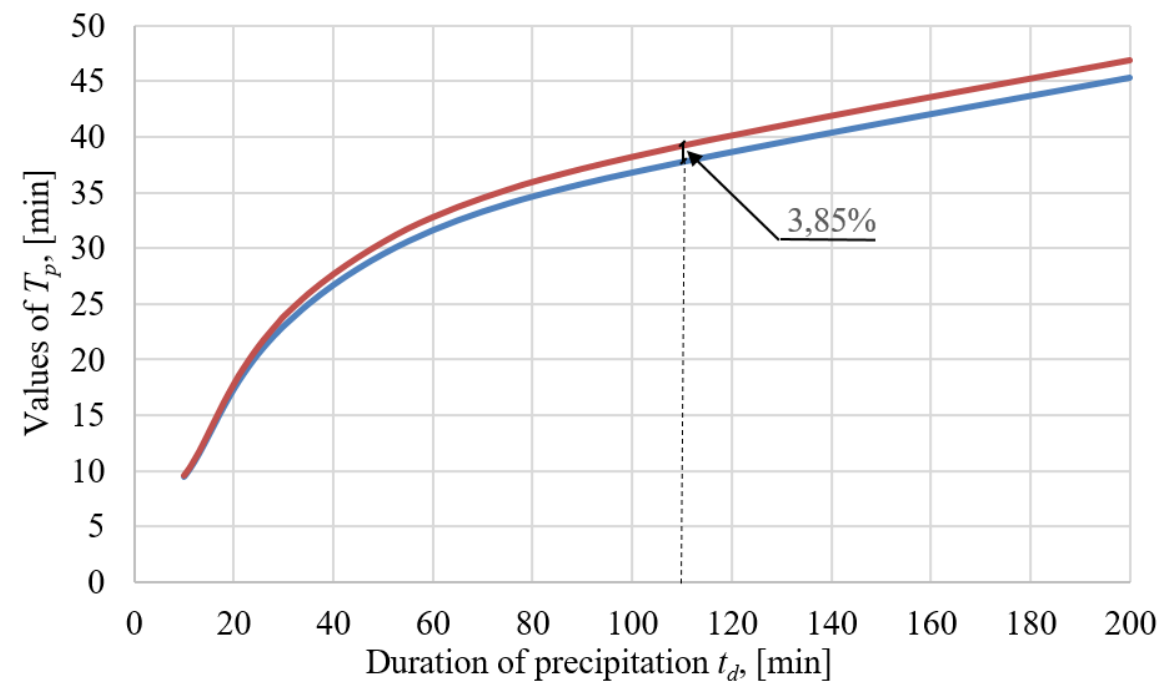

Fig. 2. $T_{p}$ values vs. the rainfall duration $t_{d}$.

The accuracy of the method developed in this work was verified by a comparison of the required detention tank service volume, determined with the hydrodynamic simulation (method no. 2) to the value determined with the formula (1) [18], with the developed artificial neural network included (method no. 1). Table 3 lists the parameters which described the sewerage catchment areas and the sewerage networks in the test analysis.

Table 3. Parameters of the sewerage catchment areas (the drainage basins) in the test analysis.

\begin{tabular}{|c|c|c|c|}
\hline Variable & Catchment I & Catchment II & Catchment III \\
\hline Catchment area drainage, $F$ & 25 ha & 50 ha & 100 ha \\
\hline Coefficient of roughness catchment, $n_{z}$ & $0,011 \mathrm{~s} / \mathrm{m}^{1 / 3}$ & $0,011 \mathrm{~s} / \mathrm{m}^{1 / 3}$ & $0,013 \mathrm{~s} / \mathrm{m}^{1 / 3}$ \\
\hline Coefficient of surface runoff, $\Psi$ & 0,70 & 0,50 & 0,30 \\
\hline Slope of catchment, $i_{z}$ & $10 \%$ & $5 \%$ & $10 \%$ \\
\hline Shape of catchment, $N$ & 1 & 5 & 2 \\
\hline Slope of sewage network, $i_{s}$ & $5 \%$ & $2 \%$ & $8 \%$ \\
\hline Catchment load, $\mathrm{Oz}$ & $8 \mathrm{ha} / \mathrm{km}$ & $4 \mathrm{ha} / \mathrm{km}$ & $12 \mathrm{ha} / \mathrm{km}$ \\
\hline
\end{tabular}

Table 4 features the determined required service volumes of the multi-chamber detention tank at the outflow of the analyzed storm sewerage systems. The values shown in bold in Table 4 were the critical required service volumes of the detention tank determined with methods no. 1 and 2 . 
Table 4. Required service volumes of the multi-chamber detention tank.

\begin{tabular}{|c|c|c|c|c|c|c|c|c|c|}
\hline & \multicolumn{3}{|c|}{ Catchment I } & \multicolumn{3}{|c|}{ Catchment I } & \multicolumn{3}{|c|}{ Catchment I } \\
\hline 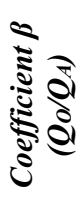 & 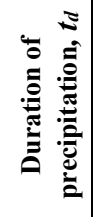 & 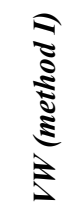 & 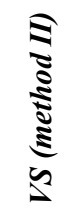 & 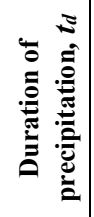 & 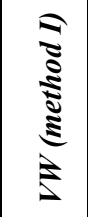 & 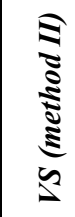 & 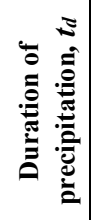 & 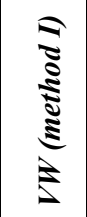 & 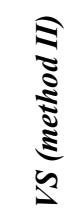 \\
\hline$[-]$ & {$[\mathrm{min}]$} & {$\left[\mathrm{m}^{3}\right]$} & {$\left[\mathbf{m}^{3}\right]$} & {$[\min ]$} & {$\left[\mathbf{m}^{3}\right]$} & {$\left[\mathbf{m}^{3}\right]$} & {$[\min ]$} & {$\left[\mathbf{m}^{3}\right]$} & {$\left[\mathbf{m}^{3}\right]$} \\
\hline \multirow{5}{*}{0.5} & 10 & 560 & 575 & 10 & 713 & 721 & 10 & 977 & 964 \\
\hline & 11 & 521 & 559 & 11 & 672 & 742 & 11 & 934 & 992 \\
\hline & 12 & 481 & 526 & 12 & 629 & 736 & 12 & 887 & 1006 \\
\hline & 13 & 443 & 493 & 13 & 586 & 694 & 13 & 839 & 992 \\
\hline & 14 & 405 & 459 & 14 & 542 & 649 & 14 & 789 & 971 \\
\hline \multirow{5}{*}{0.4} & 10 & 771 & 747 & 10 & 1018 & 1071 & 10 & 1336 & 1235 \\
\hline & 11 & 743 & 745 & 11 & 991 & 1098 & 13 & 1248 & 1317 \\
\hline & 12 & 713 & 731 & 12 & 961 & 1082 & 15 & 1173 & 1327 \\
\hline & 13 & 682 & 715 & 13 & 928 & 1050 & 17 & 1092 & 1314 \\
\hline & 14 & 651 & 698 & 14 & 893 & 1033 & 18 & 1051 & 1298 \\
\hline \multirow{5}{*}{0.3} & 10 & 1014 & 943 & 10 & 1377 & 1410 & 10 & 1752 & 1564 \\
\hline & 11 & 1003 & 955 & 11 & 1372 & 1422 & 11 & 1753 & 1621 \\
\hline & 13 & 973 & 976 & 13 & 1348 & 1434 & 19 & 1611 & 1817 \\
\hline & 14 & 955 & 985 & 14 & 1331 & 1431 & 20 & 1583 & 1811 \\
\hline & 15 & 936 & 979 & 15 & 1311 & 1428 & 21 & 1555 & 1801 \\
\hline \multirow{5}{*}{0.2} & 13 & 1315 & 1275 & 15 & 1860 & 1939 & 17 & 2348 & 2359 \\
\hline & 14 & 1317 & 1299 & 16 & 1861 & 1955 & 18 & 2349 & 2392 \\
\hline & 24 & 1251 & 1375 & 28 & 1756 & 2022 & 28 & 2269 & 2536 \\
\hline & 25 & 1240 & 1378 & 29 & 1741 & 2025 & 29 & 2255 & 2538 \\
\hline & 26 & 1229 & 1373 & 30 & 1727 & 2023 & 30 & 2241 & 2532 \\
\hline \multirow{5}{*}{0.1} & 40 & 1959 & 2047 & 40 & 2844 & 2970 & 45 & 3561 & 3775 \\
\hline & 45 & 1960 & 2072 & 45 & 2853 & 3001 & 50 & 3568 & 3808 \\
\hline & 50 & 1956 & 2086 & 50 & 2852 & 3018 & 55 & 3565 & 3826 \\
\hline & 55 & 1948 & 2091 & 55 & 2844 & 3022 & 60 & 3552 & 3830 \\
\hline & 60 & 1937 & 2090 & 60 & 2829 & 3016 & 65 & 3532 & 3823 \\
\hline
\end{tabular}


A study of the data in Table 4 revealed only some slight differences in the required service volume between methods no. 1 and 2. The application of the formula (1) with the developed artificial neural network (method no. 1) caused, in most cases, a slight misdimensioning of the required service volume when compared to the values determined with the hydrodynamic simulations (method no. 2). The highest percentage difference $(8.09 \%)$ between the required detention tank service volume $V W$ from method no. 1 and the required detention tank service volume $V S$ from method no. 2 was found in Catchment II at the wastewater flow rate reduction coefficient $\beta=0.2$.

\section{Conclusions}

The tests proved that the method formulated in Dziopak's work [18] with the inclusion of the developed artificial neural network (method no. 1) enabled an accurate reproduction of the required service volume of the multi-chamber detention tank, determined with the hydrodynamic modelling. The differences of the results for the required detention tank service volume between methods no. 1 and 2 did not exceed $\pm 10 \%$.

The tests provided a conclusion that the $T_{p}$ values varied with the rainfall duration. A relationship was found by which an increase of the rainfall duration is concomitant to an increase in the value of $T_{p}$. Note that the relationship was observed in all tested drainage basins.

The method formulated in this work can be successfully applied to produce design concepts, since it can significantly reduce the time required for design computations while retaining the concurrence of the results when compared to the applications of the professional hydrodynamic modelling-based method.

\section{References}

1. P. S. Calabro, G. Viviani, Water Res. 40, 83-90 (2006) 10.1016/j.watres.2005.10.025

2. D. Słyś, J. Dziopak, A. Raganowicz, Underground Infrastructure of Urban Areas 3, 253-260 (2015)

3. D. Słyś, J. Dziopak, Pol. J. Environ. Stud. 20, 743-753 (2011)

4. M. Starzec, J. Dziopak, D. Słyś, Underground Infrastructure of Urban Areas 4, 193200 (2018)

5. S. Kordana, E3S Web Conf. 17, 00042 (2017)

6. D. Słyś, A. Stec, M. Zeleňáková, Ecol. Chem. Eng. S 19, 359-372 (2012)

7. D. Słyś, S. Kordana, Energ. Buildings 71, 1-11 (2014)

8. S. Kordana, D. Słyś, J. Dziopak, J. Clean. Prod. 82, 58-69 (2014)

9. A. Stec, S. Kordana, D. Słyś, J. Clean. Prod. 151, 193-205 (2017)

10. J. Kaleta, M. Kida, P. Koszelnik, D. Papciak, A. Puszkarewicz, B. TchórzewskaCieślak, Arch. Environ. Prot. 43, 32-41 (2017)

11. M. Kida, S. Ziembowicz, P. Koszelnik, Sep. Purif. Technol. 192, 457-464 (2018)

12. A. Mazur, D. Słyś, E3S Web. Conf. 17, 00058 (2017)

13. A. Stec, A. Mazur, D. Słyś, E3S Web. Conf. 22, 00168 (2017)

14. D. Słyś, A. Stec, Ecol. Chem. Eng. S 21, 623-635 (2014)

15. K. Pochwat, D. Słyś, S. Kordana, J. Hydrol. 549, 501-511 (2017)

16. K. Pochwat, E3S Web Conf. 17, 00075 (2017) 
17. T. G. Schmitt, M. Thomas, N. Ettrich, J. Hydrol. 299, 300-311 (2014)

18. J. Dziopak, Analiza teoretyczna i modelowanie wielokomorowych zbiorników kanalizacyjnych (Monografia 125, Kraków, 1992)

19. E. Bogdanowicz, J. Stachy, Maksymalne opady deszczu w Polsce. Charakterystyki projektowe (Instytut Meteorologii i Gospodarki Wodnej, Warszawa, 1998)

20. L. A. Rossman, Storm water management model User's manual version 5.0. for EPA/600/R-05/040, Cincinnati, (2010) 